\title{
DEVELOPMENT OF INFORMATION SYSTEM FOR MONITORING PREGNANCY HEALTH AND NUTRITION ADEQUACY OF TODDLERS FOR STUNTING PREVENTION
}

\author{
Lailatul Hidayah" ${ }^{*}$; Doni Setio Pambudi²; Muhammad Syauqi Mubarok³ ${ }^{\text {; }}$ Ngatini $^{4}$ \\ Informatika \\ Universitas Internasional Semen Indonesia \\ info@uisi.ac.id \\ 11ailatul.hidayah@uisi.ac.id; 2doni.pambudi@uisi.ac.id; ${ }^{3}$ Muhammad.mubarok15@student.uisi.ac.id; \\ ${ }^{4}$ ngatini@uisi.ac.id
}

(*) Corresponding Author

\begin{abstract}
Stunting is a health problem caused by a lack of nutritional intake for a long time, resulting in impaired growth in children. Stunting has become one of the government's priorities due to a large number of stunting incidents in Indonesia. The lack of knowledge of mothers about nutrition and good parenting is one of the causes of stunting. Intensive provision of information and health monitoring of pregnant women from time to time will reduce the incidence of stunting in toddlers. The purpose of this research is to develop an information system that can contain various information on pregnancy health and parenting to avoid stunting and can send it regularly to the user according to their needs. This information system development adapts the Prototyping model of the Software Development Life Cycle method. The result of this study is an information system that will help disseminate various information on how to fulfill proper nutrition in pregnant and lactating mothers. Also, the system will send messages via email and Short Message Service (SMS) which will serve as reminders for patients. This information system also functions as a toddler or pregnancy health monitoring tool based on the data entered into the system. This study result tackles one of the causes of stunting, namely the lack of information on maternal health and good parenting. Researchers hope that this solution can contribute to help the government to realize its vision of reducing stunting rates in Indonesia.
\end{abstract}

Keywords: Information System, Stunting Monitoring, Toddlers

\footnotetext{
Abstrak - Stunting merupakan masalah kesehatan yang disebabkan oleh kurangnya asupan gizi dalam waktu yang cukup lama sehingga mengakibatkan gangguan pertumbuhan pada anak. Stunting telah menjadi salah satu prioritas pemerintah karena banyaknya jumlah kejadian stunting di Indonesia.
}

Minimnya pengetahuan ibu mengenai pemberian gizi dan pola asuh yang baik menjadi salah satu penyebab terjadinya stunting. Pemberian informasi secara intensif dan monitoring terhadap ibu hamil dari waktu ke waktu akan mengurangi terjadinya stunting pada balita. Tujuan dari penelitian ini adalah mengembangkan sebuah sistem informasi yang dapat memuat berbagai informasi kesehatan kehamilan dan pola asuh agar terhindar dari stunting dan dapat mengirimkannya secara berkala pada pengguna sesuai kebutuhannya. Pengembangan sistem informasi ini mengadaptasi metode pengembangan perangkat lunak model Prototyping. Hasil dari penelitian ini berupa Sistem Informasi yang akan membantu untuk melakukan diseminasi berbagai informasi mengenai cara pemenuhan gizi yang baik dan benar pada ibu hamil dan menyusui. Selain itu, sistem akan mengirimkan pesan melalui surel dan Short Message Service (SMS) yang akan menjadi pengingat bagi pasien. Sistem Informasi ini juga berfungsi sebagai alat monitoring kesehatan balita atau kehamilan berdasarkan data yang dimasukkan ke dalam sistem. Solusi ini merupakan wujud penanggulangan salah satu penyebab stunting yaitu minimnya informasi kesehatan ibu mengenai pola pengasuhan yang baik. Peneliti berharap solusi ini dapat berkontribusi untuk mempermudah pemerintah dalam mewujudkan visinya untuk mengurangi tingkat stunting di Indonesia.

Kata Kunci: Sistem Informasi, Stunting, Monitoring, Balita

\section{INTRODUCTION}

Stunting is a nutritional problem experienced by many countries, including Indonesia (Moniaga, Ohyver, Siregar, \& Yauwito, 2019). Stunting or short baby condition is a problem caused by insufficient nutritional intake for a long time, with cases that often occur in the first 1000 days of life 
(de Onis \& Branca, 2016). One in three babies under five years of age (toddlers) in Indonesia are stunted or chronically malnourished due to lack of nutritional intake starting from development in the womb. Stunting is not only a case of chronic malnutrition that causes the baby's body to become short but more than that it can give rise to problems in the development of intelligence so that it has a big impact on the future of the nation (Kementerian Kesehatan RI, 2018). Based on the data collected by the World Health Organization (WHO), Indonesia is in the third rank of countries with the highest prevalence of stunting in the Southeast Asia / South-East Asia Regional (SEAR). The average prevalence of stunting under five in Indonesia in $2005-2017$ was $36.4 \%$ (WHO, 2017). Stunting is a major nutritional problem in Indonesia. The prevalence of short children under five has increased from 2016, namely 27.5\% (Kementrian Kesehatan RI, 2017) to 29.6\% in 2017 (Kementerian Kesehatan RI, 2018).

According to the 2016 Human Development Report, Indonesia's Human Development Index (HDI) in 2015 was ranked 113th, down from the 110th position in 2014 from 188 countries, while the Intelligence Level of Indonesian children in the fields of reading, mathematics, and science was in 64th position of 65 countries. Indonesian children are also far behind children from Singapore (position 2), Vietnam (position 17), Thailand (position 50), and Malaysia (position 52) (Harsono, 2018)(WHO, 2017). In 2018 data from WHO shows that in Indonesia, 7.8 million of 23 million children under five are stunted, or around 35.6 percent. As many as 18.5 percent in the "very short" category and 17.1 percent in the "short" category. This has also resulted in WHO designating Indonesia as a country with a malnutrition status (Susilawaty \& Yulianto, 2018). Currently, Indonesia is one of the countries with a fairly high prevalence of stunting compared to other middle-income countries. Although the prevalence of stunting under five has decreased, this prevalence is still high. The government has set stunting as one of the national priorities as stated in the 2018 and 2019 Government Work Plans (RKP). In 2018, stunting handling activities were focused on 100 priority districts / cities and that number increased to 160 in 2019 (Harsono, n.d.).

Stunting occurs in various areas, both in villages and in cities, but based on research stunting is more common in villages. In fact, in $2015,30.37 \%$ of stunting occurred in villages, while for urban areas it was 7\% (Pepi, Suyatno, \& Rahfiludin, 2017). Various attempts have been made by the government in resolving these problems which require a long-term resolution with uncertain results (Kementerian Kesehatan RI, 2018).

Many factors cause stunting in Indonesia such as maternal nutritional status, breastfeeding practices, and other factors (Beal, Tumilowicz, Sutrisna, Izwardy, \& Neufeld, 2018). Among the causes is the lack of knowledge of mothers about nutrition, parenting styles that are not quite right, and limited information. The author focuses on one of the causes of stunting, namely the lack of knowledge of mothers about good parenting patterns. This can occur either because of the low level of education or the lack of information obtained by mothers during pregnancy and postpartum. The author proposes to develop an information system that can provide important knowledge needed by mothers during pregnancy and breastfeeding. This system must be able to reach patients easily. The information provided must also be by the patient's needs. This information system is expected to facilitate the dissemination of information on nutrition to the public and to monitor the development of nutrition for children under five as an effort to overcome the limitations of existing health programs and facilities. This information is adjusted to the age of pregnancy and toddlers which will be sent directly to the user's device regularly as well as presented in the form of a web-based information system. This system is also equipped with the function of monitoring child development by health workers through data entered by patients.

\section{MATERIALS AND METHODS}

\section{A. Previous Studies}

Stunting is a crucial problem in Indonesia. The need for the application of technological advances for complex health problems is rising, one of which is stunting (Huey \& Mehta, 2016). A previous study by Moniaga, J.V., et al. in 2019 developed an application to integrate data on stunting cases in Indonesia with details of their causes, which hopefully can increase the effectiveness of government measures in reducing stunting. This application implements interactive multimedia (Moniaga et al., 2019). Monitoring pregnant women and toddlers is not the main focus of this research, so this needs to be done in the research that the author conducted.

In previous studies, the relationship between the level of mother's education and the incidence of stunting in children under five was analyzed where it was found that the incidence of stunting among children under five was more common in mothers with low education because they did not have enough knowledge about the pattern of providing good nutrition for children (Kementerian 
Kesehatan RI, 2018). In line with this study, Apriluana and Fikawati reinforce this argument in their research which states that maternal education and sanitation are factors that influence the incidence of stunting (Apriluana \& Fikawati, 2018). This is influential because a good education will affect the pattern of breastfeeding practice and the provision of complementary foods (complementary foods), both of which are also factors that influence the incidence of stunting (Hidayat, 2013)(Hendra AL Rahmad, Miko, \& Novita, 2010).

In another study by Ni'mah, it was observed that many factors can cause stunting in children under five, such as the characteristics of children under five and socio-economic factors. The results obtained are that there is a very close relationship between the history of exclusive breastfeeding, family income, mother's education, and knowledge of mother's nutrition with the child's body length at birth (Ni'mah, 2015).

Furthermore, in a report entitled "100 Priority Districts/Cities for Stunting (Stunting) Intervention, it is stated that one of the causes of stunting is poor parenting practices and limited health services including ANC (Ante Natal Care) or health services for mothers during pregnancy, Post Natal Care (postnatal care), and quality early learning (Tim Nasional Percepatan Penanggulangan Kemiskinan, 2017). Therefore, it is not surprising that in their study, Ulfani et al. Found that the use of posyandu was still lacking by pregnant and lactating mothers and also that incomplete immunization for children under five was a factor causing stunting (Ulfani, Martianto, \& Baliwati, 2011). Then the strongest risk factors for stunting are non-exclusive breastfeeding, poor family latrine conditions, and the sex of the child (Gani et al., 2020). Also, the high prevalence of stunting occurred in the 18-23 month period and was significantly related to the length of the infant at birth(Hastuti, Hadju, Citrakesumasari, \& Maddeppungeng, 2020). The explanation of these studies describes the factors that influence stunting that can be implemented in this study to be used as a reference regarding the factors that influence stunting.

\section{B. Stunting}

Stunting is a condition of toddlers who have shorter lengths or height based on their age. Toddlers who are stunted are categorized as chronic nutritional problems caused by many factors such as socioeconomic conditions, maternal nutrition during pregnancy, infant illness, and lack of nutritional intake in infants. This will have an impact on difficulties in achieving optimal physical and cognitive development (Kementerian
Kesehatan RI, 2018) Stunting is a major nutritional problem faced by Indonesia. Based on Nutritional Status Monitoring (PSG) data for the last three years, short children under five have the highest prevalence compared to other nutritional problems such as malnutrition, thinness, and obesity (see Figure 1).

\section{Methodology}

The system was developed using the Software Development Life Cycle (SDLC) Prototyping model. This model is suitable for developing systems whose initial requirements are not well known and can evolve.

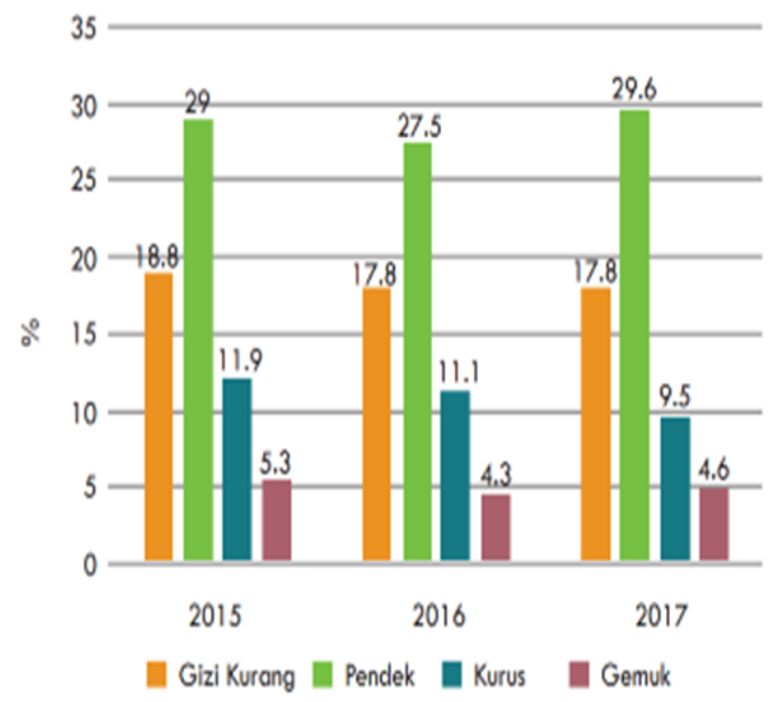

Source: (Kementerian Kesehatan RI, 2018)

Figure 1. Nutrition Problem In Indonesia

The prototype which is an early version of the system is developed quickly and then evaluated by potential users and given feedback for improvement (Purnomo, 2017). This process can be repeated until a system that meets all needs is found. The cycle of this method is depicted in Figure 2.

The types of users in this software are puskesmas staff (as admin), doctors, and patients (Member/Non-Member). In developing this software, the authors have coordinated with several potential users directly, namely the head of the puskesmas and doctors in carrying out the requirements gathering. This system requirements analysis is then documented in a simple software development reference document that will be used as a document that is used as a benchmark in designing and implementing the information system. The results of the requirements gathering are translated into a list of features and are presented in Table 1. 


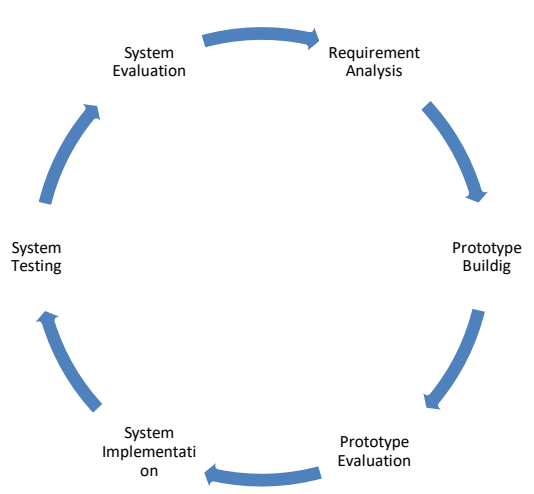

Figure 2. Prototyping Model Flow

At this stage the author also formulates a system workflow design that will be built as follows:

1. The patient logs in by entering a user name and password.

2. The patient enters the main page of the system.

3. The patient enters initial data regarding pregnancy/toddler.

4. The system will send a notification to the patient.

5. Then the system will perform a report that is displayed on the patient profile page.

Table 1. Features of First Version System

\begin{tabular}{|c|c|c|}
\hline NO. & Feature Name & Feature Explanation \\
\hline \multicolumn{3}{|c|}{ ADMIN } \\
\hline 1. & Login & $\begin{array}{l}\text { This feature is used to enter } \\
\text { the admin page using the } \\
\text { user name and password. }\end{array}$ \\
\hline 2. & Patient data & $\begin{array}{l}\text { Admin has the right to add, } \\
\text { change, } \\
\text { delete member patient data. }\end{array}$ \\
\hline 3. & Article data & $\begin{array}{l}\text { Admin can add, modify and } \\
\text { delete articles that generally } \\
\text { contain information about } \\
\text { health, pregnancy, and } \\
\text { nutrition. }\end{array}$ \\
\hline 4. & Immunization data & $\begin{array}{l}\text { Admin can add, change and } \\
\text { delete immunization data. }\end{array}$ \\
\hline 5. & Site profile data & $\begin{array}{l}\text { Admin can list the profiles of } \\
\text { government/agency as } \\
\text { pioneers of this system. }\end{array}$ \\
\hline 6. & Hospital profile data & $\begin{array}{l}\text { Admin can add, change and } \\
\text { delete profile data from } \\
\text { hospitals or health facilities } \\
\text { that work together or are } \\
\text { around the government/ } \\
\text { institution location. }\end{array}$ \\
\hline & $\begin{array}{l}\text { Data for pregnant } \\
\text { women }\end{array}$ & $\begin{array}{l}\text { Admin can add, change and } \\
\text { delete pregnant mother info. }\end{array}$ \\
\hline 8. & Toddler info data & $\begin{array}{l}\text { Admin can add, change and } \\
\text { delete toddler info. }\end{array}$ \\
\hline & Logout & $\begin{array}{l}\text { This feature is used to exit the } \\
\text { system. }\end{array}$ \\
\hline B. & DOCTOR & \\
\hline 10. & Article data & $\begin{array}{l}\text { In this feature, doctors can } \\
\text { add, modify and delete articles } \\
\text { that contain information about } \\
\text { health, pregnancy, and } \\
\text { nutrition. }\end{array}$ \\
\hline & Data for pregnant & In this feature, doctors can \\
\hline
\end{tabular}

\begin{tabular}{|c|c|c|}
\hline No. & Feature Name & $\begin{array}{l}\text { Feature Explanation } \\
\end{array}$ \\
\hline & women & $\begin{array}{l}\text { add, change and delete } \\
\text { information for pregnant } \\
\text { women. }\end{array}$ \\
\hline 12. & Toddler info data & $\begin{array}{l}\text { In this feature, doctors can } \\
\text { add, change and delete } \\
\text { information for mothers with } \\
\text { toddlers. }\end{array}$ \\
\hline C. & MEMBER PATIEN' & \\
\hline 13. & List & $\begin{array}{l}\text { This feature is used to register } \\
\text { so that the patient has } \\
\text { a user name and password that } \\
\text { is used to enter the system. }\end{array}$ \\
\hline 14. & Login & $\begin{array}{l}\text { This feature is used to enter } \\
\text { the system by filling in } \\
\text { the user name and password. }\end{array}$ \\
\hline 15. & $\begin{array}{l}\text { Notification monitori } \\
n g\end{array}$ & $\begin{array}{l}\text { This feature is only available } \\
\text { to member patients. It is a } \\
\text { feature for monitoring } \\
\text { pregnant women and toddlers } \\
\text { by sending email and SMS to } \\
\text { the member's patient's mobile } \\
\text { phone. }\end{array}$ \\
\hline 16. & Children's data & $\begin{array}{l}\text { Patient members can add, } \\
\text { modify, and delete children's } \\
\text { data. }\end{array}$ \\
\hline 17. & Toddler form & $\begin{array}{l}\text { Member patients can enter, } \\
\text { and change the child's weight } \\
\text { development data at any } \\
\text { specified period. }\end{array}$ \\
\hline 18. & Profile & $\begin{array}{l}\text { Patient members can view } \\
\text { personal data and reports on } \\
\text { the profile page. }\end{array}$ \\
\hline 19. & Pregnancy form & $\begin{array}{l}\text { Member patients can enter and } \\
\text { modify pregnancy progression } \\
\text { data at any specified period. }\end{array}$ \\
\hline & Logout & $\begin{array}{l}\text { This feature is used to exit the } \\
\text { system. }\end{array}$ \\
\hline
\end{tabular}

\section{System Design}

1. Use Case Diagram

Use case diagrams are made based on the analysis that has been carried out on the running process based on the activities of all actors. Use Case Diagram of the overall system is presented in Figure 3.

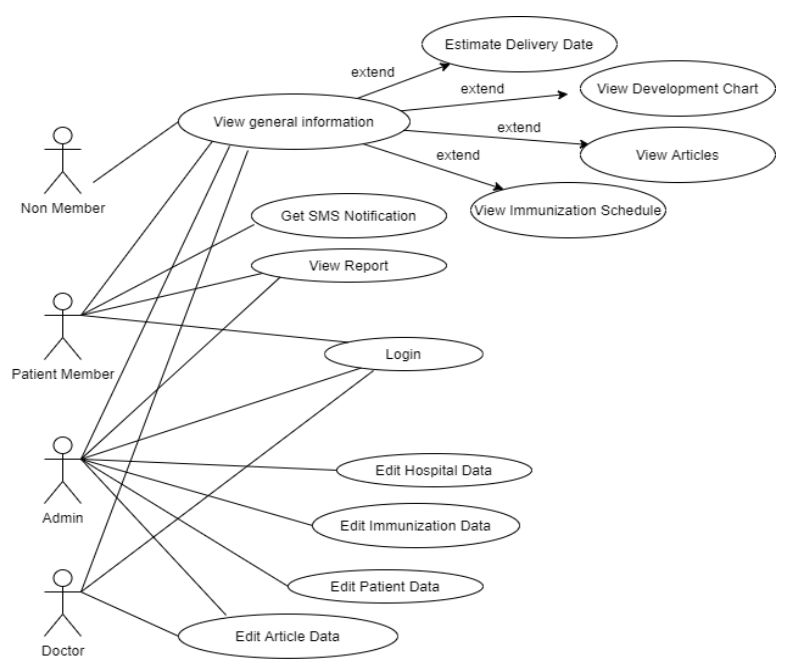

Figure 3. Use Case Diagram 
a. Use Case Diagram Login

Use Case Login Diagrams describe the entire process carried out by admin, doctor, and patient member. Every process of the use case is subject to a credential checking instance. There are different types of users and each type has different user access rights. This mechanism is designed to limit the access privileges for each user type such as to differentiate the rights between patient members and patients non-member. Details of the login use case diagram can be seen in Figure 4.

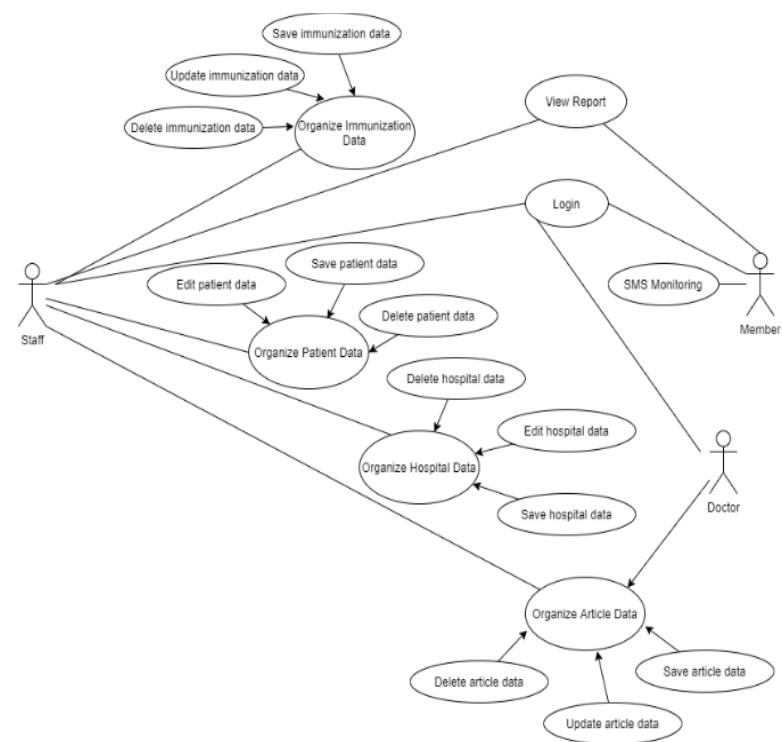

Figure 4. Use case diagram login

b. Use Case Diagram Non-Login

Non-login use case diagrams illustrate the entire process carried out by admins, doctors, member patients, and non-member patients. The entire process in this use case runs without going through the login action and all users can easily access it. Details of the Non-Login Use Case Diagram are presented in Figure 5.

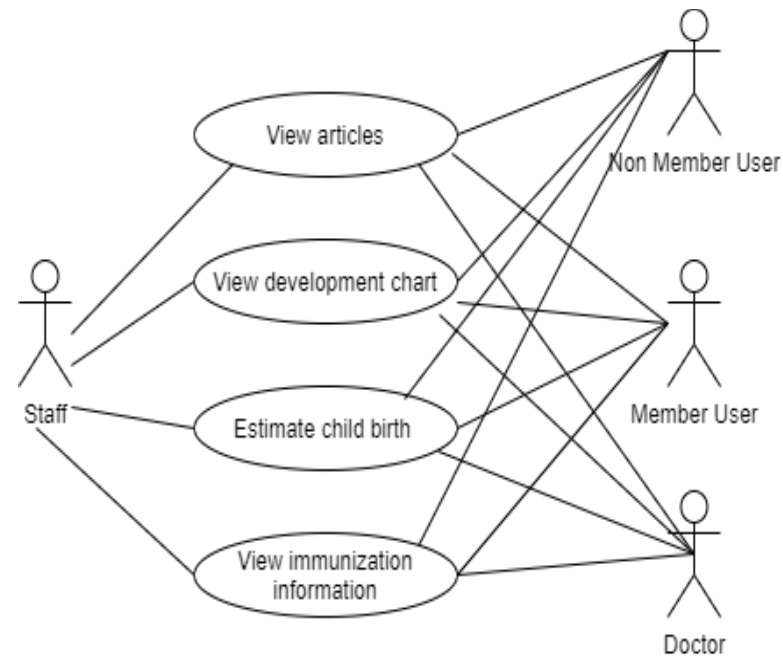

Figure 5. Use Case Diagram Non-Login

\section{Activity Diagram and Class Diagram}

An activity diagram is used to explain the flow of work which is owned by each use case. So that there is at least one activity diagram in one use case. Figure 6 shows one of the Activity diagrams in designing this system. Figure 7 shows the class diagram required in the system design.

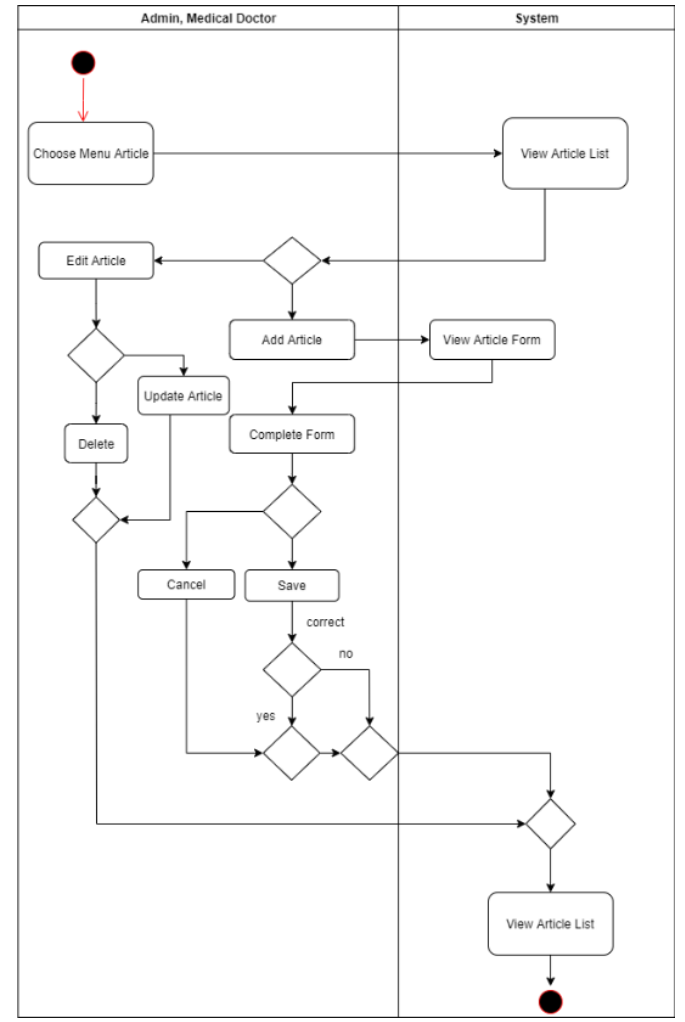

Figure 6. Activity diagrams of the admin and doctor process managing article data

\section{a. Sequence Diagram}

The sequence diagram is depicted based on the class diagram and refers to the activity diagram that has been made. The sequence diagram illustrates the interaction of the sequence of events based on time. Figure 8 shows a sequence diagram of the process of sending email and SMS. This diagram illustrates the activity flow when the system checks the date and after that, the system will send email and SMS simultaneously.

\section{b. System Architecture}

The information system architecture is displayed in Figure 9. The information system is built in the form of a website that is connected to a database server and an SMS server (SMS server). All users access the web server through their respective browsers on their PC/laptop or smartphone. Notifications are sent directly to members' devices via the SMS Server. 

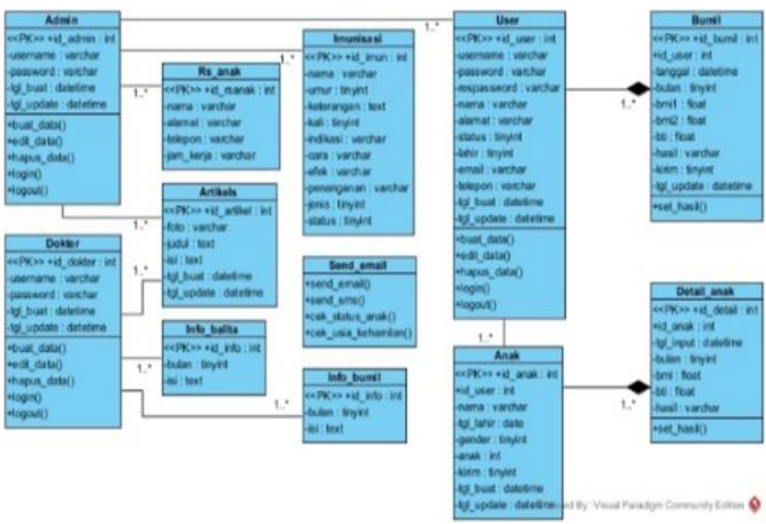

Figure 7. General class diagram

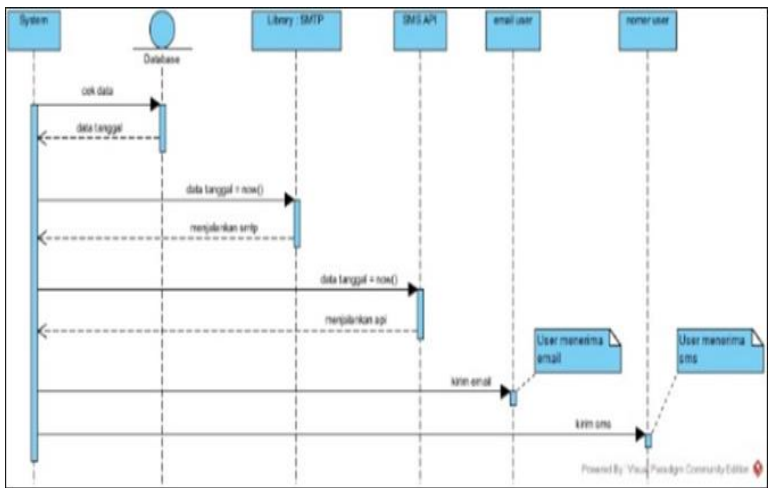

Figure 8. Sequence Diagram for Email and SMS Sending

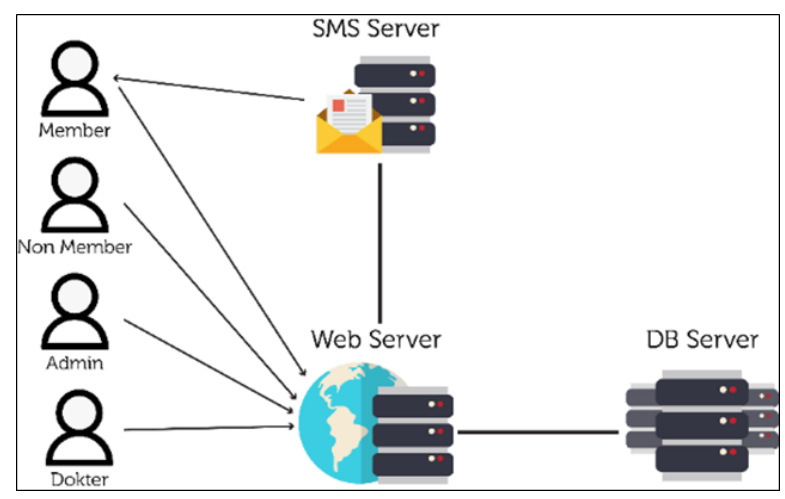

Figure 9. System Architecture

\section{RESULTS AND DISCUSSION}

A. User Interface Display

1) Information System Main Page

The main page can be accessed by users without going through the login page. This page contains mostly articles about pregnant women and toddlers. A screenshot of this page is presented in Figure 10.

2) Immunization page

The Immunization page contains information on various types of immunizations from ages 0 to 18 years and details how many times they should be administered. The immunization page can be seen in Figure 11.

\section{3) KMS chart}

KMS graph depicts the development of weight and height of children under five from time to time. The KMS graphic is shown in Figure 12. The X-axis represents the span of your growing period, while the Y-axis represents your weight or height. On the lower left of the image, a red graph shows a plot of the patient's weight/height so that it can be compared directly with the average child's condition according to WHO standards. Dark green areas represent normal or average child development while light green and yellow areas represent areas where the child is developing more than average (for the upper area) and less than average (for the lower area).

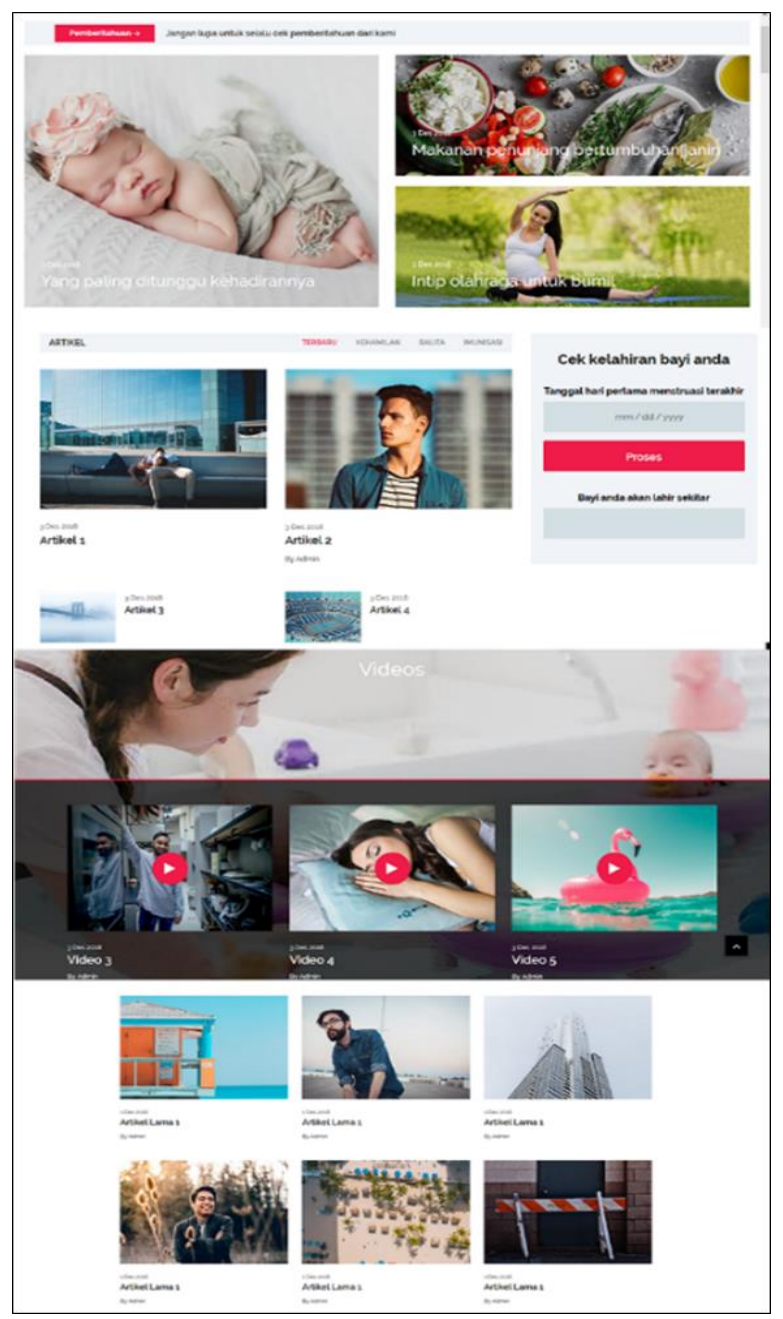

Figure 10 Information System Main Page 


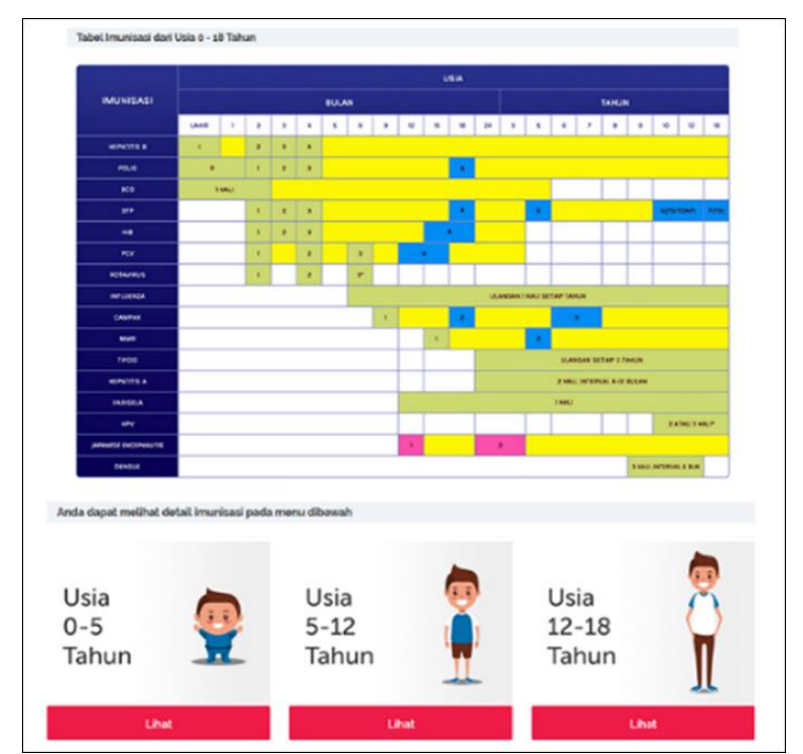

Figure 11. Immunization table page

\section{4) Pregnant Women report page}

The report contains data that is derived from a form that is completed monthly and displayed as tables and graphs and only holds five (5) latest data items. To see all report, patient's member must press the button "View All Data" which are under the report table. The pregnant women report page can be seen in Figure 13.

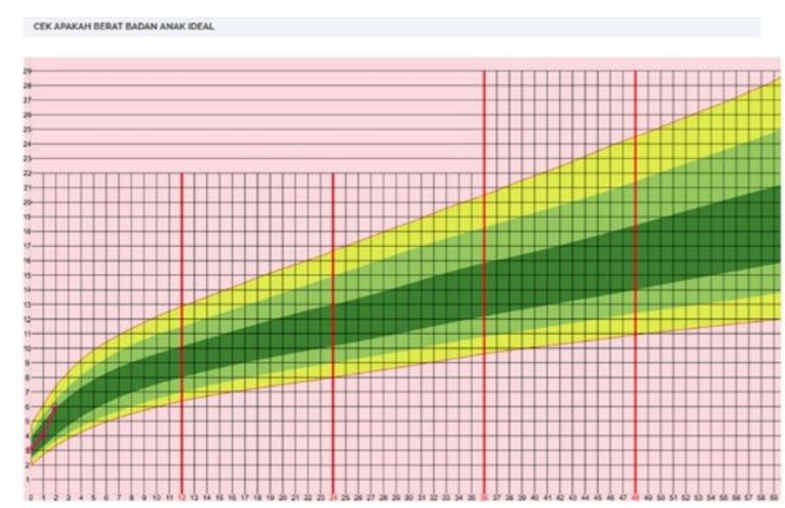

Figure 12 Display of Child Development Report in KMS Graph

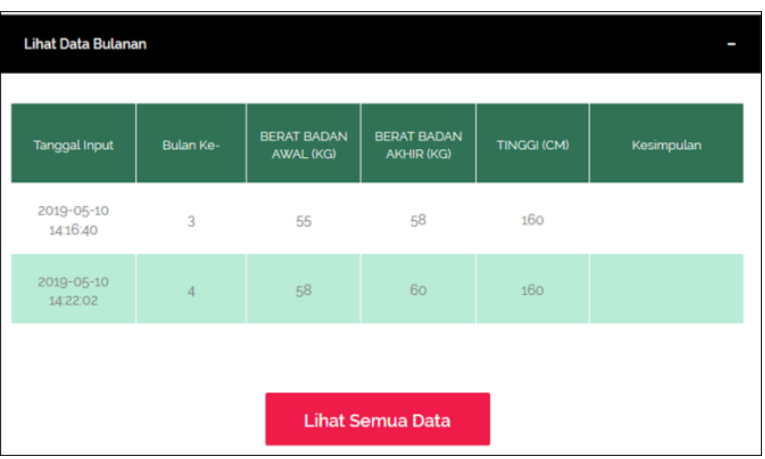

Figure 13 Pregnant Women Report Page
5) Child Report Page

This page shows all data of children of the patient. Member patients can edit or delete the data. The child report page contains monthly data that has been entered by the patient's member namely weight and height data. The children's report page can be seen in Figure 14 and Figure 15.

6) Message page

After account registration, the patient member will receive an email that contains verification of the account automatically. The e-mail will tell you that the account has been made and ready to be used. Besides that, periodically pregnant patients and children under five will receive the reminder messages by the conditions of each. Figure 16 shows an example of reminder messages received in e-mail and SMS.

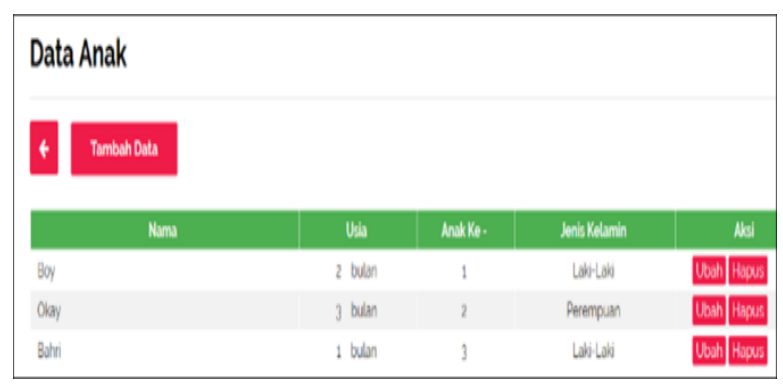

Figure 14 Child List Page

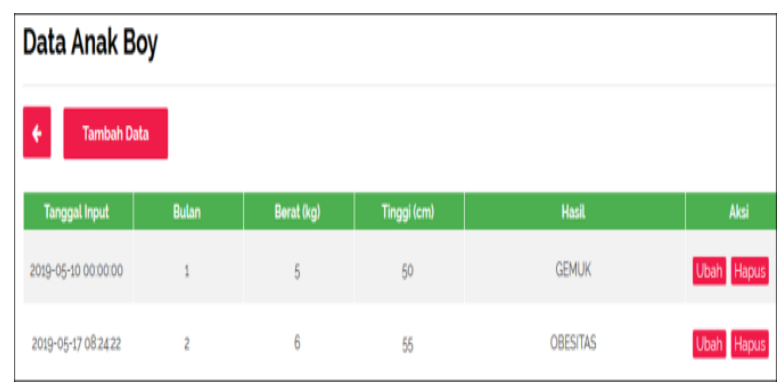

Figure 15 Each Child's Report Page

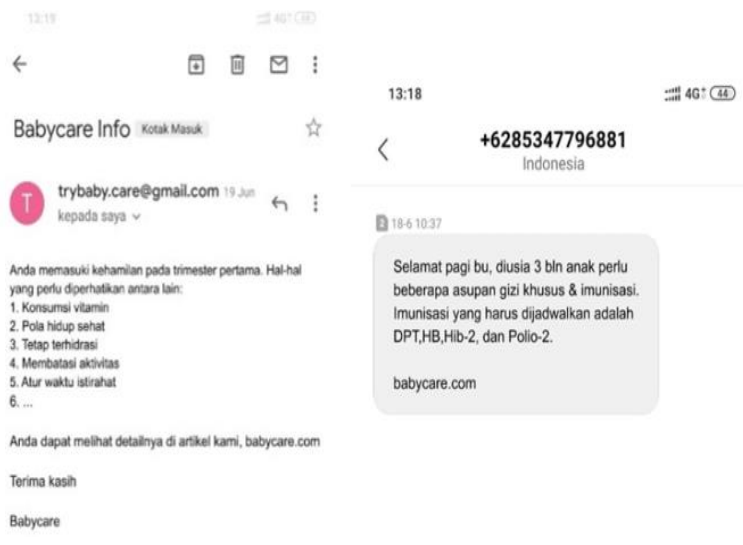

Figure 16 Reminder messages via Email and SMS 


\section{B. Testing}

System testing is carried out to test all elements of the software whether they have met the requirements. The test method used is the Black Box testing method. The Black Box testing method evaluates the fundamental aspects of the system without paying attention to the internal logic structure of the software. This method is used to find out whether the software is functioning properly and correctly. After testing the system using the Black Box method, the data is summarized into tables. This table is made as a measure of the success of the system that has been created. Details of system test results can be seen in Table 2. In the system test stage, the author is assisted by a user who acts as a patient who registers to be a member of this information system and also by a user who is a doctor.

Table 2. User Acceptance Test Documents Version

\begin{tabular}{|c|c|c|c|c|}
\hline NO & \multicolumn{2}{|c|}{ Use Case/Proses } & $\begin{array}{l}\text { Status } \\
\text { It }\end{array}$ & \multirow[t]{2}{*}{$\begin{array}{l}\text { Date and } \\
\text { Examiner }\end{array}$} \\
\hline 1 & $\begin{array}{l}\text { - Test } \\
\text { name } \\
\text { - Test } \\
\text { description } \\
\text { - Test case } \\
\text { - the } \\
\text { expected } \\
\text { results }\end{array}$ & $\begin{array}{l}\text { : Clear data } \\
\text { : The only be } \\
\text { accessed by admin } \\
\text { : User data } \\
\text { : - If successful will } \\
\text { display a list of user } \\
\text { data } \\
\text { - If it fails, it will } \\
\text { display an error } \\
\text { message. }\end{array}$ & $\begin{array}{l}\text { It } \\
\text { works }\end{array}$ & \\
\hline 2 & $\begin{array}{l}\text { - Test } \\
\text { name } \\
\text { - Test } \\
\text { description } \\
\text { - Test case } \\
\text { - the } \\
\text { expected } \\
\text { results }\end{array}$ & $\begin{array}{l}\text { : KMS page } \\
: \text { Can only be } \\
\text { accessed by member } \\
\text { patients } \\
: \text { KMS graph } \\
: \text { - If successful will } \\
\text { display the KMS } \\
\text { page }\end{array}$ & $\begin{array}{l}\text { It } \\
\text { works }\end{array}$ & \multirow[t]{2}{*}{$\begin{array}{l}25 \text { June } \\
2019 \\
\text { By } \\
\text { Doctor }\end{array}$} \\
\hline 3 & $\begin{array}{l}\text { - Test } \\
\text { name } \\
\text { - Test } \\
\text { description } \\
\text { - Test case } \\
\text { - the } \\
\text { expected } \\
\text { results }\end{array}$ & $\begin{array}{l}\text { : Register patient } \\
\text { accounts } \\
\text { : Create a new } \\
\text { patient account } \\
\text { : Patient data } \\
\text { : - If successful the } \\
\text { account will be } \\
\text { registered, and the } \\
\text { patient member will } \\
\text { receive an email. } \\
\text { After the patient } \\
\text { member can } \\
\text { perform login } \\
\text { - If this fails, the } \\
\text { account is detected } \\
\text { as invalid or already } \\
\text { registered. }\end{array}$ & $\begin{array}{l}\text { It } \\
\text { works }\end{array}$ & \\
\hline \multirow[t]{2}{*}{4} & \multirow{2}{*}{$\begin{array}{l}\text { - Test } \\
\text { name } \\
\text { - Test } \\
\text { description } \\
\text { - Test case } \\
\text { - the } \\
\text { expected } \\
\text { results }\end{array}$} & \multirow{2}{*}{$\begin{array}{l}\text { : Admin login: } \\
\text { : Verify access rights } \\
\text { : User name and } \\
\text { password } \\
: \text { - If successful will } \\
\text { display the main } \\
\text { page } \\
\text { - If it fails, it will } \\
\text { display a login page }\end{array}$} & $\begin{array}{l}\text { It } \\
\text { works }\end{array}$ & $\begin{array}{l}13 \text { June } \\
2019 \text { by } \\
\text { Patient }\end{array}$ \\
\hline & & & $\begin{array}{l}\text { It } \\
\text { works }\end{array}$ & $\begin{array}{l}28 \text { June } \\
2019 \text { by } \\
\text { Doctor }\end{array}$ \\
\hline
\end{tabular}

\begin{tabular}{|c|c|c|c|c|}
\hline \multirow[t]{2}{*}{ NO } & \multicolumn{2}{|c|}{ Use Case/Proses } & \multirow[t]{2}{*}{ Status } & \multirow[t]{2}{*}{$\begin{array}{r}\text { Date and } \\
\text { Examiner }\end{array}$} \\
\hline & & $\begin{array}{l}\text { and an error } \\
\text { message. }\end{array}$ & & \\
\hline \multirow[t]{2}{*}{5} & \multirow{2}{*}{$\begin{array}{l}\text { - Test } \\
\text { name } \\
\text { - Test } \\
\text { description } \\
\text { - Test case } \\
\text { - the } \\
\text { expected } \\
\text { results }\end{array}$} & \multirow{2}{*}{$\begin{array}{l}\text { : Login doctor } \\
\text { : Verify access rights } \\
\text { : Username \& } \\
\text { password } \\
\text { :- If successful will } \\
\text { display the main } \\
\text { page } \\
\text { - If it fails, it will } \\
\text { display a login page } \\
\text { and an error } \\
\text { message. }\end{array}$} & $\begin{array}{l}\text { It } \\
\text { works }\end{array}$ & $\begin{array}{l}13 \text { June } \\
2019 \text { by } \\
\text { Patient }\end{array}$ \\
\hline & & & $\begin{array}{l}\text { It } \\
\text { works }\end{array}$ & $\begin{array}{l}28 \text { June } \\
2019 \text { by } \\
\text { Doctor }\end{array}$ \\
\hline \multirow[t]{2}{*}{6} & \multirow{2}{*}{$\begin{array}{l}\text { - Test } \\
\text { name } \\
\text { - Test } \\
\text { description } \\
\text { - Test case } \\
\text { - the } \\
\text { expected } \\
\text { results }\end{array}$} & \multirow{2}{*}{$\begin{array}{l}\text { : Register patient } \\
\text { accounts } \\
: \text { Create a new } \\
\text { patient account } \\
\text { : Patient data } \\
:- \text { If successful the } \\
\text { account will be } \\
\text { registered, and the } \\
\text { patient member will } \\
\text { receive an email. } \\
\text { After the patient } \\
\text { member can } \\
\text { perform login } \\
\text { - If this fails, the } \\
\text { account is detected } \\
\text { as invalid or already } \\
\text { registered. }\end{array}$} & $\begin{array}{l}\text { It } \\
\text { works }\end{array}$ & $\begin{array}{l}13 \text { June } \\
2019 \text { by } \\
\text { Patient }\end{array}$ \\
\hline & & & $\begin{array}{l}\text { It } \\
\text { works }\end{array}$ & $\begin{array}{l}28 \text { June } \\
2019 \text { by } \\
\text { Doctor }\end{array}$ \\
\hline
\end{tabular}

\section{CONCLUSION}

The prototype of the information system has been developed and has accommodated the needs that have been identified previously, namely sending health information for pregnant women and toddlers regularly according to the age of pregnancy/toddler to the patient, processing data entered by patients to be presented in the form of informative reports to patients and make it easier for health workers to control the health conditions of pregnant women and toddlers. The information system is expected to help the government in addressing the problem of stunting in Indonesia. Development of this system will continue further. The dissemination of information and the use of the system is expected to provide benefit to the public either directly or indirectly. In addition to the impact of health that directly can be felt, the use of the system is also expected to be able to collect the data of patients which then can be analyzed and become the basis of another feature development especially one which is associated with artificial intelligence artificial in which the data becomes very important for its development. The information system that has been developed can be further improved by other features such as stunting risk prediction feature or further developed for use on smartphones, namely on Android and/or iOS platforms. 


\section{ACKNOWLEDGEMENT}

We convey our gratitude to KEMENRISTEKDIKTI for providing research grants for the Beginner Lecturer Research (Penellitian Dosen Pemula) scheme in 2020. Besides, we would like to thank LPPM UISI for its support in the implementation of this research.

\section{REFERENCE}

Apriluana, G., \& Fikawati, S. (2018). Analisis Faktor-Faktor Risiko terhadap Kejadian Stunting pada Balita (0-59 Bulan) di Negara Berkembang dan Asia Tenggara. Media Penelitian Dan Pengembangan Kesehatan, 28(4), 247-256 https://doi.org/10.22435/mpk.v28i4.472

Beal, T., Tumilowicz, A., Sutrisna, A., Izwardy, D., \& Neufeld, L. M. (2018). A review of child stunting determinants in Indonesia. Maternal and Child Nutrition, 14(4). https://doi.org/10.1111/mcn.12617

de Onis, M., \& Branca, F. (2016). Childhood stunting: A global perspective. Maternal and Child Nutrition, 12, 12-26. https://doi.org/10.1111/mcn.12231

Gani, A. A., Widasari, L., Otoluwa, A. S., Hadju, V., Palutturi, S., Thaha, A. R., \& Manti B, S. (2020). Risk factors for stunting among children in Banggai Regency, Indonesia. Enfermeria Clinica, 30, 149-152. https://doi.org/10.1016/j.enfcli.2019.10.058

Harsono, F. H. (n.d.). HEADLINE: Bahaya Stunting dan Ancaman Lost Generation, Indonesia Harus Berbuat Apa?

Harsono, F. H. (2018). Bahaya Stunting dan Ancaman Lost Generation, Indonesia Harus Berbuat Apa?

Hastuti, Hadju, V., Citrakesumasari, \& Maddeppungeng, M. (2020). Stunting prevalence and its relationship to the birth length of 18-23 months old infants in Indonesia. Enfermeria Clinica, 30, 205-209. https://doi.org/10.1016/j.enfcli.2019.10.069

Hendra AL Rahmad, A., Miko, A., \& Novita, R. (2010). Kajian Stunting pada Anak Balita Ditinjau dari Pemberian ASI Eksklusif, MPASI , Status Imunisasi dan Karakteristik Keluarga di Kota Banda Aceh. Nasuwakes Poltekkes NAD, 4, 36-72.

Hidayat, R. (2013). Sistem Prediksi Status Gizi Balita Dengan Menggunakan Support Vector Regression. Departemen Ilmu Komputer Fakultas Matematika Dan Ilmu Pengetahuan Alam Institut Pertanian Bogor.

Huey, S. L., \& Mehta, S. (2016). Stunting: The Need for Application of Advances in Technology to
Understand a Complex Health Problem. EBioMedicine, 6, 26-27. https://doi.org/10.1016/j.ebiom.2016.03.01 3

Kementerian Kesehatan RI. (2018). Buku Saku Pemantauan Status Gizi Tahun 2017. In sehatnegeriku.kemkes.go.id. Jakarta: Kementerian Kesehatan. Retrieved from https://sehatnegeriku.kemkes.go.id/wpcontent/uploads/2018/01/Buku-SakuNasional-PSG-2017-Cetak-1.pdf

Kementrian Kesehatan RI. (2017). Buku Saku Pemantauan Status Gizi Tahun 2016. In kesmas.kemkes.go.id. Jakarta: Kementerian Kesehatan RI. Retrieved from https://kesmas.kemkes.go.id/assets/uploads /contents/others/Buku-Saku-Hasil-PSG2016_842.pdf

Moniaga, J. V., Ohyver, M., Siregar, J., \& Yauwito, P. H. (2019). Map-type modeling and analysis of children stunting case data in Indonesia with the interactive multimedia method. Procedia Computer Science, 157, 530-536. https://doi.org/10.1016/j.procs.2019.09.010

Ni'mah, K. (2015). Faktor yang Berhubungan dengan Kejadian Stunting pada Balita. Media Gizi Indonesia, 10(1), 13-19.

Pepi, A., Suyatno, \& Rahfiludin, M. Z. (2017). Perbedaan Karakteristik Balita Stunting di Pedesaan dan Perkotaan Tahun 2017. Jurnal Kesehatan Masyarakat, 5(4), 600-612.

Purnomo, D. (2017). Model Prototyping Pada Pengembangan Sistem Informasi. J I M P Jurnal Informatika Merdeka Pasuruan, 2(2), 54-61.

https://doi.org/10.37438/jimp.v2i2.67

Susilawaty, D., \& Yulianto, A. (2018, January 24). WHO: 7,8 Juta Balita di Indonesia Penderita Stunting. Republika.Co.Id, p. Nasional. Retrieved from https://www.republika.co.id/berita/nasional /umum/18/01/24/p30s85396-who-78-jutabalita-di-indonesia-penderita-stunting

Tim Nasional Percepatan Penanggulangan Kemiskinan. (2017). 100 Kabupaten/Kota Prioritas untuk Intervensi Anak Kerdil (Stunting) (1st ed.). Jakarta: TNP2K. Retrieved from http://www.tnp2k.go.id/images/uploads/do wnloads/Binder_Volume1.pdf

Ulfani, D. H., Martianto, D., \& Baliwati, Y. F. (2011). Faktor-Faktor Sosial Ekonomi Dan Kesehatan Masyarakat Kaitannya Dengan Masalah Gizi Underweight, Stunted, Dan Wasted Di Indonesia: Pendekatan Ekologi Gizi. Jurnal Gizi Dan Pangan, 6(1), 59. https://doi.org/10.25182/jgp.2011.6.1.59-65 WHO. (2017). Stunted Growth and Development. 
18 Jurnal PILAR Nusa Mandiri Vol. 17, No. 1 March 2021

WHO Press. Retrieved from https://www.who.int/nutrition/childhood_st unting_framework_leaflet_en.pdf

P-ISSN: 1978-1946 | E-ISSN: 2527-6514 | Development of Information System ... Rank 3 Accredited Journal based on Decree No. 85/M/KPT/2020 DOI: $10.33480 /$ pilar.v17i1.1783 